\title{
Instructors' Attitudes toward Active Learning
}

\author{
David Pundak \\ Kinneret College on the \\ Sea of Galilee, Israel, and \\ ORT Braude College, \\ Israel
}

dpundak@gmail.com

\author{
Orit Herscovitz \\ ORT Braude College, Israel, \\ and Department of Education in \\ Technology and Science, at the \\ Technion, Israel Institute of \\ Technology, Israel
}

orither@techunix.technion.ac.il

\section{Miri Shacham and Rivka Wiser-Biton ORT Braude College, Israel}

\author{
mshacham@netvision.net.il; rivkaw@braude.ac.il
}

\begin{abstract}
Material published as part of this publication, either on-line or in print, is copyrighted by the Informing Science Institute. Permission to make digital or paper copy of part or all of these works for personal or classroom use is granted without fee provided that the copies are not made or distributed for profit or commercial advantage AND that copies 1) bear this notice in full and 2) give the full citation on the first page. It is permissible to abstract these works so long as credit is given. To copy in all other cases or to republish or to post on a server or to redistribute to lists requires specific permission and payment of a fee. Contact Publisher@InformingScience.org to request redistribution permission.
\end{abstract}

One of the major goals of science and technology education today is to promote students' active learning as a way to improve students' conceptual understanding and thinking skills. Although there is clear evidence for the benefits of active learning, most lecturers in higher education still adhere to traditional teaching methods. This research seeks to identify the characteristic attitudes of "active instructors" towards active learning and discerning a distinction between these attitudes and those of the remaining instructors. This study examined the attitudes of 153 lecturers in three higher education institutions in Israel. The research tool was an attitude questionnaire developed specially for this study on the basis of the experience of 7 "active instructors" exposing the process of change they had undergone moving from traditional teaching to more active instruction. An analysis of these interviews provided the basis for characterizing the attitudes of "active instructors" and subsequently for the development of the research questionnaire. On the basis of a literature review and an examination of the attitudes of the "active instructors," a content analysis was undertaken in which the attitudes were grouped into six key domains that can characterize the tendency of a lecturer to adopt active teaching. The findings reveal that in all these 6 domains there were significant differences between the attitudes of "active instructors" and their colleagues. This diagnostic tool can supply crucial information to the college and universities directors when planning supportive steps toward advancing active learning in their institutions.

Keywords: Active learning, instructors' attitudes, traditional learning vs. active learning, Scale-Up, innovation.

\section{Editor: Alex Koohang}

An earlier, shorter version of this paper was presented at the Chais conference 2009, in Raanana, Israel, and included in Y. Eshet-Alkalai, A. Caspi, S. Eden, N. Geri, \& Y. Yair (Eds.), Proceedings of the Chais conference on instructional technologies research 2009: Learning in the technological era. Raanana: The Open University of Israel. http://www.openu.ac.il/research center eng/conferences.html 


\section{Introduction}

Over the past decade, researchers and instructors in Israel and around the world have attempted to promote active learning in academic courses. The process of introducing innovation in teaching based on the adoption of active teaching approaches is a long and complex one (Dori et al., 2003; Dori \& Herscovitz, 2005; Pundak, Maharshak \& Rozner, 2004, Pundak, Rozner, Yacobson, \& Toledano-Kitay, 2008). In many fields of teaching it is difficult to introduce innovations even when this would clearly be advantageous and beneficial (Rogers, 1995). The Israeli Ministry of Education has recently begun to promote inquiry learning designed to encourage students and teachers to teach in a more meaningful manner. This approach develops inquisitive and creative thought. It is mirrored by the demand to prepare students for the matriculation examinations - a process which, in many cases, encourages learning by rote and algorithmic learning rather than the development of higher cognitive skills (Dori et al., 2003).

Institutions of higher education also engage with this dilemma. These institutions strive to conform to a packed and demanding curriculum that leaves little time for students to develop a profound understanding of the study subjects. Studies examining innovative teaching methods that involve the students in conducting lectures in basic courses in sciences, engineering, and technology suggest that these methods result in enhanced achievements among the students, a better understanding of the studied material, involvement, and responsibility for the learning process (Barak, Harward, Kocur, \& Lerman, 2007; Dori \& Belcher, 2005; Jose \& Pedrosa, 2005; Snellman, Krueger, \& Unangst, 2006).

\section{Active Learning in Academic Institutions}

Numerous evaluation studies have been undertaken in the United States to examine the advantages of active learning in appropriately-adapted classes. One of the active learning environments developed at the start of the twenty-first century is the SCALE-UP (Student-Centered Active Learning Environment for Undergraduate Programs) environment. This approach emphasizes active learning by students in large classes including fifty or more students. Classrooms in this environment were described in detail by Beichner (Beichner, Saul, Allain, Deardorff, \& Abbott, 2000; Beichner et al., 2007), who developed the approach. Students in these classes sit at round desks, each of which has room for nine students. Every three students form a group. A significant proportion of the lesson time is devoted to activities by the students, such as problem solving, simulation, laboratory investigations, researching websites, writing a position paper, or undertaking a task. The researchers ran tests in institutions adopting this teaching method in order to gauge the level of conceptual understanding of the studied subjects at the beginning and end of the course. These tests were identical to the accepted tests in the academic world in the US and, accordingly, could provide a basis for fair comparison between traditional teaching and active teaching. The researchers interviewed students, held discussions with focus groups, examined the students' files, undertook observations, and prepared audio and video recordings of hundreds of hours of active teaching (Beichner et al., 2007).

\section{Active Learning and Conceptual Understanding}

A wide range of evidence supported the concept that active learning students achieve higher conceptual understanding compared to other students who studied the same courses according to the traditional learning approach (Dori \& Belcher, 2005). The idea that "active learning only supports the under- achiever student and neglects future stars" is in many cases invalid. In a large scale study of 6500 students studying according to active learning methods, Hake (1998) found that stronger students exhibited greater improvement of conceptual understanding of Newtonian physics compared to other less skilled-students.. Nevertheless, according to Hake's study, both popula- 
tions improved their conceptual understanding more than students who studied according to traditional learning methods.

\section{Active Learning and Higher Thinking Levels}

One of the most significant aims of the active learning approach is to develop high level thinking skills. Students are asked to solve problems according to the scientific method. They collect, analyze, interpret and represent data, and relying on this procedure they design a system, component, or process to meet desired needs (Etkina \& Van Heuvelen, 2001).

One of the first educators to address the issue of different levels of thinking skills was Bloom (1956). According to Bloom's taxonomy of learning domains (1956), there are three domains of educational activities: (1) The Cognitive Domain, which involves knowledge and the development of intellectual and mental skills; (2) The Affective Domain, which describes the way we face things emotionally, such as feelings, appreciation, values, enthusiasm, attitudes, and motivations; and (3) The Psychomotor Domain, which involves physical movement, coordination, and use of the motor-skill. Bloom described six sub-categories in the cognitive domain, which are measured by degrees and levels of difficulties so that an individual cannot master one of these levels if he/ she has not first mastered the preceding sub-category. The lowest thinking skill category is (1) knowledge (involving recall data or information); followed by (2) comprehension (interpretation of instructions, translation, understanding the meaning); (3) application (implementation of learned information or an abstraction to understand a novel situation); (4) analysis (separation of material or concepts into component parts, in order to understand the complexity of the organizational structure); (5) synthesis (composition of new structure or pattern from diverse elements); and the final and the highest order component of the cognitive domain, (6) evaluation (making judgments about the value of ideas or materials).

According to the active learning approach, team-work in small groups plays a crucial part in the lesson. Practicing exercises in problem-solving leads students to pay attention to their thinking strategies. The new knowledge that they develop is organized, analysed, applied, and evaluated through thinking procedures (Zohar \& Dori, 2003). 'High level thinking' is an action hard to define, but it is possible to characterize it by some key qualities, which are recognized when they occur (Resnick, 1987). This type of thinking is not algorithmic, and the thinking and action patterns students have to choose cannot be clearly pre-determined. In many cases the students' products are multiple solutions and each of them has advantages and disadvantages. In many cases uncertainty is an immanent part in high level thinking, and it necessitates a high level of independence, judgment and decision making (Dori \& Herscovitz, 1999; Zoller, 1987).

Studies conducted in Michigan and North Carolina universities show that students' learning by team work in small groups during the lessons is much more valuable and fruitful than learning in traditional lectures halls (Abbott, Saul, Parker, \& Beichner, 2000; Henderson \& Dancy, 2008; Gavalcova 2008) investigated the teaching of mathematic principles in universities according to the active learning approach. Her findings point up strategies developed by instructors, including open discussions and explanations. These strategies enhance student thinking skills, for example, asking questions and conceptualizing answers. She found that in active learning the students advanced from questions at a low thinking level such as "how to calculate?" or "what is my mistake?" to a higher level of thinking such as "why does it work this way?", "what is the reason for this procedure?" or "where can we find the same patterns?" The students understood the importance of theory as a key to understanding mathematical principles. They also internalized the importance of general concepts and their contribution to effective solutions of various mathematical problems (Zweck, 2006). 
In a research on Computer Supported Collaborative Learning (CSCL) environments, Ada (2009) found a positive correlation between the quality of the group's engagement in a collaborative process and the quality of cognitive skills fostered. She asserted that "high levels of social interaction and collaboration contributed to the establishment of a community of learning, nurturing a space for fostering higher order thinking through co-creation of knowledge processes" (p.145).

\section{Students' Satisfaction regarding Active Learning}

In active learning in the SCALE-UP environment in the US, students are not required to attend class. Despite this, average attendance in the University of North Carolina is as high as ninety percent. Most of the students choose to study in this format in their second year of studies on the basis of recommendations from fellow students. The percentage of dropouts from active courses using this approach was measured at Florida International University and was found to be onefourth of the dropout rate for similar courses using traditional teaching approaches. The level of satisfaction of students and instructors at FIU with the course using the active teaching method was particularly high in comparison to other courses. Following their exposure to this teaching method, ten to twenty percent of students chose to focus on science studies (Kramer, Brewe, \& O'Brien, 2008). In conclusion, most researchers who examined active learning identified an improvement in the following indices: conceptual understanding, test achievements, reduced dropout rates, student satisfaction, team work, and problem solving.

\section{Instructors' Perceptions of Active Learning}

Numerous studies have been undertaken in recent years regarding instructors' perceptions of their function in academic institutions. Some researchers have made a distinction between perceptions focused on the instructor regarding the transmission of knowledge and information, perceptions focused on the instructor-student relations, and perceptions focused on the student's activities and the development of understanding and conceptualization (Gerlese \& Akerlind, 2004; Kember, 1997; Samuelowicz \& Bain, 2001).

Freire (1970) related critically to the "banking" approach to education - a metaphor used by Freire to suggest that students should be considered as empty bank accounts that should remain open to deposits made by the teacher. Education becomes an act of depositing, in which the teacher is the depositor and the students are depositories patiently receiving, memorizing, and repeating the deposited data transferred by the teacher; there is no chance for active communication. Freire rejects this "banking" approach, claiming that it results in the dehumanization of both the students and the teachers. In addition, he argues that the banking approach stimulates oppressive attitudes and practices in society Additionally, Freire claims that knowledge emerges only through invention and re-invention, through restless and impatient, hopeful inquiry, when human beings communicate with each other and interact with the world. The approach of active learning is opposed to the "banking" model of passive student absorption of information from an authority figure and focuses instead on the student-teacher dialogue and the development of active knowledge construction by the students.

Most academic instructors tend to adhere to traditional teaching approaches, according to which the principal function of the instructor is to convey knowledge. In traditional teaching the students generally remain passive and are not invited to express their opinion, cope with problems, or consider possible solutions (Harmin, 2006; Redish, 2003).

In a study that interviewed 332 instructors and teachers (Niemi, 2002), the respondents noted six factor/ variables that they felt prevented them from engaging in teaching that promote active learning:

A. Lack of time due to the need to complete all the required material in a packed curriculum. 
B. Teaching in large groups does not permit active teaching.

C. A shortage of study materials suitable for the active teaching approach.

D. Opposition among senior peers to changes after they have developed teaching methods suited to their capabilities and experience.

E. A lack of meta-cognitive skills and motivation on the part of the students. The instructors feel that students prefer traditional learning.

F. Among high school teachers, parental opposition to change was also mentioned.

In addition to these factor/variables, instructors argue that difficulties occur in the assimilation of active learning when students lack background knowledge in the studied subject. Active learning also demands more work from both instructors and students than traditional teaching (Scheyvens, Amy, \& Griffin, 2008). It seems that the reluctance to adopt instruction innovations is also related to the professional development of the instructors. Burke (1987) argues that professional development occurs in three cycles: Induction, Renewal and Redirection. The first cycle - induction is characterized by worries and attempts to survive (Huberman, 1993). These feelings are not limited to the first time that the instructors stand in front of the students, but often recur during their instructional career, for example, when an instructor answers the need or demand to change instructing methods and attempts to replace traditional instruction with active instruction.

The tendency to focus on the instructors' reluctance to use teaching innovations, mainly to promote active learning, in order to explain the lack of use of these innovations neglects another important component: the students' expectations from learning. In many cases students prefer an instruction style that allows their passive participation in the lesson and where the instructor presents the learning material in a clear manner and solves all the problems expected to be included in the final exam for them (Slater, 2003). The students, like instructors, who are used to the traditional learning, are not eager to adapt to new learning environments. Consequently, instructors who enthusiastically adopt new methods are often frustrated by their students' responses (Felder \& Brent, 1996).

\section{Background and Research Goals}

With the goal of promoting meaningful active learning by students and integrating innovative teaching approaches, the management of an academic engineering college in Northern Israel decided to integrate active learning courses at the college. The course environments integrated various technologies such as a learning web-site that accompanied the course, web assignments and checkers, a computer network in the active learning class, and discussion groups (Pundak \& Rozner, 2007). Over the past five years, approximately ten instructors at the college have been involved in a program focusing on the development of innovative teaching technologies and the transition from traditional teaching to teaching for active learning. The instructors participated in workshops offering an introduction to teaching methods for active learning and subsequently prepared learning kits for introductory courses at the college in mathematics, physics, and chemistry (Pundak \& Rozner, 2006). The active learning environments included group activities by students during the lecture, conceptual tests, peer teaching (Mazur, 1997), active demonstration (Cooper \& Robinzon, 2000), simulations (Dori et al., 2003), group problem-solving (Redish, 2003), integration of a web-based task examiner (Pundak et al., 2004), a dynamic course website (Scheyvens et al., 2008), and 'just in time' teaching (Beichner et al., 2000).

In interviews with these instructors (hereinafter - the 'active instructors') they reported significant changes in their attitudes to teaching and in the perception of the students' learning process in the courses they taught according to this approach. Over the years, the remaining instructors at the college were offered workshops presenting various components of active learning. Participation 
in these workshops was partial, and their influence on the instructors has not yet been examined. Following changes in the perception of teaching and learning among the 'active instructors', it was decided to attempt to examine attitudes regarding active learning among all the instructors in the college, in order to identify those instructors whose perceptions were closer to those of the 'active instructors'. The assumption was that these instructors would be more willing to change their teaching methods.

The research goals included identification of the characteristic attitudes of 'active instructors' toward active learning and discerning a distinction between these attitudes and those of the remaining instructors in the college.

The research goals were derived from the following research questions:

A. What are the characteristics of the attitudes of the 'active instructors' toward active learning?

B. Is there any gap, and if so how large, between the attitudes of the 'active instructors' and the attitudes of the other instructors in academic institutions regarding active learning?

\section{The Research Population}

The study was carried out among 153 instructors at one university and two colleges and also seven 'active instructors' who had been involved in the development of active teaching methods and gained experience of this approach in standard-size classes. The 'active instructors' are faculty members at the college from various disciplines who spent three years developing active study materials and implementing these materials in a special classroom.

The special active learning classroom - Scale Up - was developed at the college on the basis of studies undertaken at the University of Northern Carolina and at MIT (Beichner et al., 2007).

\section{Development of the Research Process and Tool}

The research tool was an attitudes questionnaire developed specially for the purpose of this study on the basis of the experience of the 'active instructors' and interviews with those instructors exposing the process of change they had undergone. Over the five-year period in which active learning was developed and integrated in basic courses at the college, the 'active instructors' were interviewed twice in each semester. An analysis of these interviews provided the basis for characterizing the attitudes of 'active instructors' and subsequently for the development of the research questionnaire.

It is possible to assess the significant change in the attitude of an 'active instructor' toward active teaching from her words in an interview we conducted with her two years after she began to teach with active learning methods:

It is an amazing process [and I can see] how the students are beginning to construct their knowledge and how it develops along the course. Each student has its own rhythm. It seems as though the student's head is transparent and we can trace how their knowledge is developed and organized.

One of the new challenges for the traditional instructor who begins to use the active learning approach is how to manage students learning in small groups. During an interview with one of the 'active instructors' she described the influence of learning in small groups on her as instructor and on students' involvement.

In the traditional classes it was impossible to provide personal guidance for the student. In contrast, in an active class, when I approach a group of three or 
even nine students all of them listen to me... group work contributes a lot to the group members. In addition to my impressions I listened to the students' testimonies. The group constitutes a supportive environment. If one of the group members presents an issue to the class and encounters difficulties the rest of the group support him.

On the basis of a review of the literature (Johnson, Johnson, \& Smith, 1998) and an examination of the attitudes of the 'active instructors', a content analysis was undertaken in which the attitudes were grouped into six key domains in which it is possible to distinguish tendencies that characterize an instructor who is inclined to use teaching methods of active teaching. These domains are:

(1) Large Class - Activation of a large class

(2) Involvement - Student involvement in the course

(3) Independence - Independent learning by students

(4) Development of knowledge - by students

(5) Quantity versus understanding - A tendency to prefer understanding of the material to full completion of the syllabus

(6) Function of instructor - Perception of the role of the instructor.

Table 1 presents the six domains identified as characterizing the attitudes of the 'active instructors', as well as the ways in which these attitudes are manifested in active learning in comparison to the attitudes identified with traditional teaching.

Table 1 Description of the Six Domains addressed by the Research Questionnaire and their Manifestation in Traditional Teaching/Learning and Active Teaching

\begin{tabular}{|l|l|l|l|}
\hline No. & $\begin{array}{l}\text { Domain of teaching / } \\
\text { learning }\end{array}$ & $\begin{array}{l}\text { Manifestation in } \\
\text { traditional teaching }\end{array}$ & $\begin{array}{l}\text { Manifestation in active } \\
\text { teaching }\end{array}$ \\
\hline 1 & large classes & $\begin{array}{l}\text { There is no requirement to } \\
\text { activate the students in a } \\
\text { large class and they } \\
\text { cannot be guided }\end{array}$ & $\begin{array}{l}\text { Students in a large class should } \\
\text { be activated, particularly by } \\
\text { means of group work }\end{array}$ \\
\hline 2 & Involvement & $\begin{array}{l}\text { Participation in classes is } \\
\text { optional; students succeed } \\
\text { in the course if they pass } \\
\text { the final test }\end{array}$ & $\begin{array}{l}\text { Student participation in classes } \\
\text { is vital in order to ensure that } \\
\text { they understand the study } \\
\text { material and are successful in } \\
\text { the course }\end{array}$ \\
\hline 3 & Independence & $\begin{array}{l}\text { Students should not be } \\
\text { expected to have } \\
\text { knowledge of study topics } \\
\text { not presented in class by } \\
\text { the instructor }\end{array}$ & $\begin{array}{l}\text { Students can learn by } \\
\text { themselves topics from the } \\
\text { syllabus, if they receive proper } \\
\text { guidelines }\end{array}$ \\
\hline 4 & $\begin{array}{l}\text { Development of } \\
\text { knowledge }\end{array}$ & $\begin{array}{l}\text { The students' level of } \\
\text { scientific knowledge does } \\
\text { not enable them to } \\
\text { develop new scientific } \\
\text { knowledge }\end{array}$ & $\begin{array}{l}\text { Students can present new } \\
\text { scientific arguments and ideas } \\
\text { by themselves }\end{array}$ \\
\hline
\end{tabular}




\begin{tabular}{|l|l|l|l|}
\hline No. & $\begin{array}{l}\text { Domain of teaching / } \\
\text { learning }\end{array}$ & $\begin{array}{l}\text { Manifestation in } \\
\text { traditional teaching }\end{array}$ & $\begin{array}{l}\text { Manifestation in active } \\
\text { teaching }\end{array}$ \\
\hline 5 & $\begin{array}{l}\text { Quantity versus } \\
\text { understanding }\end{array}$ & $\begin{array}{l}\text { It is important to teach the } \\
\text { whole syllabus; students } \\
\text { should not be expected to } \\
\text { gain a profound } \\
\text { understanding }\end{array}$ & $\begin{array}{l}\text { It is important for students to } \\
\text { understand the basis concepts of } \\
\text { the course as a foundation for } \\
\text { more complex scientific } \\
\text { knowledge }\end{array}$ \\
\hline 6 & Function of instructor & $\begin{array}{l}\text { The instructors should } \\
\text { focus on their function as } \\
\text { transmitters of knowledge }\end{array}$ & $\begin{array}{l}\text { The instructor should identify } \\
\text { the students' learning } \\
\text { difficulties and develop } \\
\text { appropriate teaching methods }\end{array}$ \\
\hline
\end{tabular}

The domains of teaching/learning identified on the basis of the experience of the 'active instructors' are consistent with Constructivist Theory and the approach of participatory learning in small groups. According to these approaches, the learning process, the development of a conceptual world, and the connections between the two are undertaken actively by the learner through the process of coping with different possibilities and examining these against the background of reality in team work (Vygotsky, 1978, pp. 79-91).

\section{Questionnaire Validation}

Construction and validation of the questionnaire was carried out in three stages. The first stage was the phrasing of 50 statements regarding instruction in both traditional and active learning, and their categorization within the six domains described in Table 1. Positive and negative statements, regarding active learning point, were phrased for each of these domains. These 50 statements were then presented to 7 experts in learning and teaching at our college. According to their responses 6 statements were eliminated so the first version [V1] of research tool contains 44 statements.

At the second stage questionnaire V1 was administered to 8 'active instructors'. As a result of analysis of the instructors responses 7 statements were removed. 37 statements were selected for the second version [V2] of research questionnaire with 75\% higher agreement (at least 6 instructors out of 8).

At the third stage questionnaire V2 was administered to 7 experts in teaching and learning from the Department of Education in Technology and Science in the Technion (Israel Institute of Technology - IIT). The group from the IIT was a validation group and did not take part in the research group. As a result of their responses, 2 more statements were eliminated and some slight modifications were applied to 4 other statements. The last version of research tool [V3] contains 35 statements and it appears in the Appendix.

\section{Questionnaire Reliability}

To improve our categorization of the six domains we adopted a blended approach of two philosophies 'predeterminism' and 'row statistics', suggested by Adams et al. (2006). We took advantage of the strengths of both approaches and avoided the weaknesses to obtain statistically robust categories that best characterize instruction thinking in the academic context for which this questionnaire was constructed. Guided by the research results, we then grouped the statements into new categories that were likely to be useful and were evaluated as statistically valid. These categories were not necessarily independent and not all statements needed to be ascribed to a category. This 
approach was justified because the different aspects of the instructors' beliefs were not necessarily independent; rather, an attempt was made to identify which portions of the data were useful to describe particular general aspects of the instructors' thinking.

The research questionnaire was presented to 153 instructors at three academic institutions. A Factor/ variable Analysis was undertaken in order to improve the division into teaching/learning domains. Questionnaire reliability was examined using Cronbach's Alpha, yielding the value 0.753. Instructors' responses were processed to produce the 35 statements included in the questionnaire using the SPSS program. The analysis of items was undertaken in stages: in each stage, one domain was identified and its reliability level was determined using Cronbach's Alpha. At the end of the process, the statements were divided into the six teaching/learning domains. Table 2 present the summary of the item analysis.

Table 2 Examination of the Reliability of the Six Teaching/Learning Domains by Means of a Factor/ variable Analysis

\begin{tabular}{|l|l|c|c|}
\hline No. & Teaching/Learning Domain & $\begin{array}{l}\text { Number of } \\
\text { Statements in the } \\
\text { Domain }\end{array}$ & $\begin{array}{l}\text { Cronbach's } \\
\text { Alpha }\end{array}$ \\
\hline 1 & Activation of a large class & 7 & 0.797 \\
\hline 2 & Student involvement in course & 5 & 0.478 \\
\hline 3 & Independent learning by students & 6 & 0.589 \\
\hline 4 & $\begin{array}{l}\text { Development of knowledge by } \\
\text { students }\end{array}$ & 6 & 0.683 \\
\hline 5 & Quantity versus understanding & 6 & 0.656 \\
\hline 6 & Function of the instructor & 5 & 0.669 \\
\hline
\end{tabular}

As a rule of thumb, researchers require a reliability of 0.70 or higher (obtained on a substantial sample) before they will use an instrument. According to this rule the questionnaire is reliable. This is also true for learning domain 1 - Activation of a large class. Results of analysis for the other three domains $(4,5,6)$ came quite close to the threshold of 0.7 . Results for the last two domains $(2,3)$ are lower.

\section{Research Findings and Discussion}

\section{Differences between Faculty Members and 'Active Instructors'}

The study compared the average score of the attitudes of the instructors $(\mathrm{N}=153)$ in each of the six domains examined with the average attitudes of the 'active instructors' group ( $\mathrm{N}=7)$. The comparison of averages was undertaken using Kruskal-Wallis parameter free analysis. Table 3 presents the results of the comparison. The ranking of the attitudes was determined on the basis of the research questionnaire; a high ranking reflects a tendency on the part of the instructors to engage in promoting active learning, while a low ranking reflects a tendency to traditional teaching. 
Table 3 Comparison between the Ranking of Attitudes of Faculty Members and the Ranking of 'Active Instructors' in Six Domains of Teaching/Learning according to a Kruskal-Wallis Test

\begin{tabular}{|c|c|c|c|c|c|c|}
\hline $\begin{array}{l}\text { Domain / } \\
\text { Variable }\end{array}$ & 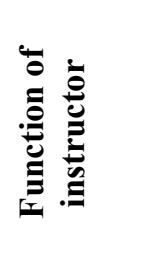 & & 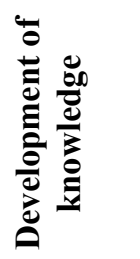 & 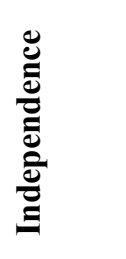 & 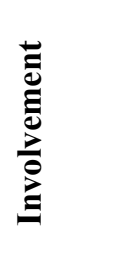 & 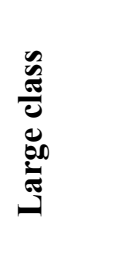 \\
\hline $\begin{array}{l}\text { Ranking of } \\
\text { faculty } \\
\text { members }\end{array}$ & 24.1 & 23.9 & 24.2 & 24.3 & 24.3 & 23.5 \\
\hline $\begin{array}{l}\text { Ranking of } \\
\text { 'active } \\
\text { instructors' }\end{array}$ & 46.1 & 47.6 & 45.6 & 44.5 & 44.6 & 49.8 \\
\hline $\begin{array}{l}\text { Difference in } \\
\text { ranking }\end{array}$ & 22.0 & 23.7 & 21.4 & 20.2 & 20.3 & 26.3 \\
\hline Chi squared & 12.5 & 14.5 & 11.8 & 10.5 & 10.7 & 17.7 \\
\hline Significance & $<0.001$ & $<0.001$ & 0.001 & 0.001 & 0.001 & $<0.001$ \\
\hline
\end{tabular}

The results in Table 3 reflect a significant difference in all six domains addressed by the research questionnaire between the average attitudes of faculty members and those of the 'active instructors' group. Three most significant differences were evident between these two groups.

The findings of the study show that the largest gap between the ranking of the 'active instructors' and the other instructors (26.3) was in the domain of activation of a big-size class. The 'active instructors' believe that it is possible for students in a large class to be active or take part in active processes and to be divided into small learning groups. A plenum session can be used to guide the students and to develop productive discussion. Most of the faculty members tend to believe that discussions in a large class create noise and do not lead to any progress in learning the study material. The faculty members' attitude is that it is impossible to achieve personal contact with students in groups or as individuals in a large class. The structure of the lectures by 'traditional instructors' focuses mainly on course content and less on the manner in which the students interpret this content or integrate it within their prior knowledge. A 'traditional instructor' does not usually address the social process involved in group activation and seems to be unaware of this process. Conversely, 'active instructors' who have experienced group work note the importance of involving students in the course and enabling them to achieve its objectives.

A further prominent difference between 'active instructors' and 'traditional instructors' relates to the importance of achieving understanding versus quantity in the curriculum (23.7). 'Active instructors' prefer to move forward with the study material only after ensuring that most of the students in the course have reached an adequate level of understanding of the study material, whereas 'traditional instructors' prioritize the demand to complete the course studies, even if this means that students do not properly understand the study material.

The third domain that exhibited a large gap (22.0) between the groups was the function of instructor. While the tendency of most faculty members was to emphasize the role of instructor as the 'knowledge deliverer', the 'active instructors' related to this point only as one role among many others that the instructor should fulfill. In addition to transmitting knowledge, according to 'active 
instructors', the instructor should have other roles such as recognizing students' difficulties, guiding students in various assignments during the lessons, directing the groups' work, encouraging students to present their solutions in front of class, raising their level of thinking, and developing methods for the students to provide feedback to one another.

These gaps and the other three, point up large differences between faculty members who did not make efforts to create an appropriate atmosphere in class that could help prepare students to face the needs of the future employers (Etkina \& Van Heuvelen, 2001) and those who are trying to devise and employ new teaching methods.

\section{Tendencies of Faculty Members to Adopt Active Learning Methods}

Despite the evident differences between the attitudes of 'active instructors' and the other instructors toward active learning, we assumed that some components of active learning infiltrate into the pedagogy of the latter. In order to evaluate the tendency of these instructors at academic institutions to adopt active learning we built a linear model using an Active Learning Coefficient (ALC). The ALC was calculated as an average of the instructors' attitudes toward active learning. The questionnaire contains positive and negative statements relating to active learning. To calculate the ALC the instructors' attitudes regarding a negative statement (Xn) were converted to positive position $(\mathrm{Xp})$ by $\mathrm{Xp}=6-\mathrm{Xn}$. Where the value of $\mathrm{Xp}$ is in the range $1 \leq \mathrm{Xp} \leq 5$. The value of ALC for each instructor was calculated by the following equation:

$$
A L C=\sum_{i=1}^{35} \frac{X p_{i}}{35}
$$

where i denotes the questionnaire index number and $35(\mathrm{~N})$ is the number of items in the questionnaire. A linear regression was made on ALC, by ANOVA. The results of the linear regression are presented in Table 4.

Table 4 Models of active learning tendency of instructors in academic institutions. The three models were developed by linear regression

\begin{tabular}{|ll|l|l|l|l|l|}
\hline Model & & $\begin{array}{l}\text { Sum of } \\
\text { Squares }\end{array}$ & $\begin{array}{l}\text { Degree of } \\
\text { Freedom } \\
\text { (df) }\end{array}$ & $\begin{array}{l}\text { Mean } \\
\text { Square }\end{array}$ & F & Significance \\
\hline 1 & Regression & 9.492 & 1 & 9.492 & 119.887 & $.000^{(\mathrm{a})}$ \\
& Residual & 4.038 & 152 & .079 & & \\
& Total & 13.530 & 153 & & & \\
2 & Regression & 12.047 & 2 & 6.024 & 203.186 & $.000^{(\mathrm{b})}$ \\
& Residual & 1.482 & 151 & .030 & & \\
& Total & 13.530 & 153 & & & \\
3 & Regression & 12.707 & 3 & 4.236 & 252.222 & $.000^{(\mathrm{c})}$ \\
& Residual & .823 & 150 & .017 & & \\
& Total & 13.530 & 153 & & & \\
\hline
\end{tabular}

a. Model 1 - only large class

b. Model 2 - large class + quantity/understanding

c. Model 3 - large class + quantity/understanding + independence. 
From the results presented in Table 4 it seems that Model 1 explains $70.2 \%$ of the variance of the faculty members' attitudes toward the use of active learning instruction in a large class (domain 1).

Model 2, is a combination of two domains 1 and 5 (quantity/understanding) and it explains $89.0 \%$ of the variance of ALC.

Model 3 includes three domains $1+5+3$ (independence) it explains 93.9\% from the variance of ALC.

According to these results pedagogy in large classes is the domain with the largest variance between the faculty members. Some faculty members still teach according to unchanged 'good old' methods they learnt as students in institutions all over the world - 'talk and chalk'. Other divided their lectures into segments and in between these segments conducted discussions. Another group of faculty members used presentations with animations and active demonstrations, and some instructors used an array of different methods for active learning (Cooper \& Robinson 2000).

\section{Summary and Conclusions}

One of the major goals of science and technology education today is to promote students' active learning as a way to improve students' conceptual understanding and thinking skills. Although there is clear evidence for the benefits of active learning, most lecturers in higher education still adhere to traditional teaching methods. The first step in order to integrate innovation into teachers' instruction is to reveal their attitudes towards such innovations. In this research we identified and characterized six domains in which it was possible to distinguish different attitudes towards active learning and constructed an attitude questionnaire based on these domains. This questionnaire was developed on the basis of the experience of 'active instructors' and interviews with them, and validated by teaching instructors from several academic institutions.

Our diagnostic tool, the questionnaire, allows schools and institutions to indicate the extent attitudes of their faculty tendency toward active learning. The diagnostic tool supplies crucial information to the college and universities directors when planning supportive steps toward advancing active learning in their institutions. In some countries a gap has been found between higher education institutions and high schools in the implementation of active learning (Dori \& Herscovitz, 1999, 2005; Zohar \& Dori, 2003). While in high schools the adoption rate of active learning approaches is quite high, in academic institutions only a small fraction of instructors award attention to this approach, and an even smaller fraction consider its adoption for their teaching (Harmin, 2006; Redish, 2003). The present authors believe that active learning could contribute to students' involvement and achievements in academic courses and that their tool (questionnaire) could help instructors to plan the adoption of this approach

This questionnaire can serve as a practical tool to identify instructors whose attitudes are close to those of 'active instructors' and may be open to the use of innovative methods. The specially designed research tool can be used to locate these instructors and suggest that they join the group of instructors using the active teaching approach.

The largest gap found between 'active instructors' attitudes and the other instructors' attitudes was in the domain of activation of a large class. This indicates a large gap between what traditional instructors believe can be done in large classes and what 'active instructors' believe can be done to promote active learning. These issues should be addressed by teacher training developers, by providing greater focus for methods and instructions guiding the activation of students in large classes and by conducting training courses and seminars to promote active learning.

Base on our six domains of active learning perceptions, we suggest the following six aspects that should be addressed by teacher training developers: 
1. Ways for activate students in a large class, particularly by means of group work;

2. Encourage student participation in classes in order to ensure that they understand the study material and are successful in the course;

3. Give students the opportunity to learn by themselves topics from the syllabus, following proper guidelines;

4. Involve students in assignments that force them to present new scientific arguments and ideas by themselves;

5. Give more importance on students' understanding of the basis concepts of the course as a foundation for more complex scientific knowledge;

6. Identify students' learning difficulties and develop appropriate teaching methods in order to assist students.

The increasingly large classes prevalent in academic institutions, the strong need to reduce expenses, and institutional pressure on staff to spend more time on research rather than instruction, directs faculty staff toward the traditional approach. On the other hand the results from science education research and success in implementation of active learning methods in many institutions encourage faculty members to adopt this innovative approach. Online resources play an important role by supplying information and methods to advance the students' involvement in academic learning. The deliberation between traditional and active instruction is still ongoing and so far traditional instruction is still the favorite. We hope that our facilitating tool will contribute modest support to change what we believe to be an unjustified and unbalanced situation.

\section{References}

Abbott, D. S., Saul, J. M., Parker, G. W., \& Beichner, R. J. (2000). Can one lab make a difference? American Journal of Physics, 68(S1), 60-61.

Ada, W.W. (2009). Computer supported collaborative learning and higher order thinking skills: A case study of textile studies. Interdisciplinary Journal of E-Learning and Learning Objects, 5, 145-167. Retrieved from http://ijello.org/Volume5/IJELLOv5p145-167MA657.pdf

Adams, W. K., Perkins, K. K., Podolefsky, N. S., Dubson, M., Finkelstein, N. D., \& Wieman, C. E. (2006). New instrument for measuring student beliefs about physics and learning physics: The Colorado Learning Attitudes about Science Survey. Physical Review Special Topics - Physics Education Research, 2, (1). http://prst-per.aps.org/abstract/PRSTPER/v2/i1/e010101

Barak, M., Harward, J., Kocur, G., \& Lerman, S. (2007). Transforming an introductory programming course: From lectures to active learning via wireless laptops. Journal of Science Education and Technology, 16(4), 325-336.

Beichner, R. J., Saul, J. M., Allain, R. J., Deardorff, D. L., \& Abbott, D. S. (2000). Promoting collaborative groups in large enrollment courses. Proceedings of the Annual Meeting of the American Association of Physics Teachers.

Beichner, R., Saul, J., Abbott, D., Morse, J., Deardorff, D., Allain, R., Bonham, S., Dancy, M., \& Risley, J (2007). Student-Centered Activities for Large Enrollment Undergraduate Programs (SCALE-UP) project. In E. F. Redish \& P. J. Cooney (Eds.), Research-based reform of university physics. College Park, MD: American Association of Physics Teachers.

Bloom, B. S. (1956). Taxonomy of educational objectives, Handbook I: The cognitive domain. New York: David McKay Co.

Burke, P.J. (1987). Teacher development - Induction, renewal and redirection. New York: Falmer Press.

Cooper, J. L., \& Robinson, P. (2000). The arguments for making large classes seem small. New Directions for Teaching and Learning, 81, 5-16. 
Dori, Y. J., \& Belcher, J. W. (2005). How does technology-enabled active learning affect students' understanding of scientific concepts? The Journal of the Learning Sciences, 14(2), 243-279.

Dori, Y. J., Belcher, J. W., Bessette, M., Danziger, M., McKinney, A., \& Hult, E. (2003). Technology for active learning. Materials Today, 6(12), 44-49.

Dori, Y. J., \& Herscovitz, O. (1999). Question-posing capability as an alternative evaluation method: Analysis of an environmental case study. Journal of Research in Science Teaching, 36, 411-430.

Dori, Y. J., \& Herscovitz, O. (2005). Case-based long-term professional development of science teachers. International Journal of Science Education, 27(12), 1413-1446.

Etkina, E. and Van Heuvelen, A. (2001). Investigative Science Learning Environment: Using the processes of science and cognitive strategies to learn physics, in Proceedings of the 2001 Physics Education Research Conference, 17-21.

Felder, R. M., \& Brent, R. (1996). Navigating the bumpy road to student-centered instruction. The College Teaching, 44, 43-47.

Freire, P. (1970). Pedagogy of the oppressed. New York: Continuum.

Gavalcova, T (2008). On strategies contributing to active learning. Teaching Mathematics and its Applications, 27( 3), 116-122.

Gerlese, S., \& Akerlind, G. S. (2004, July). A new dimension to understanding university teaching, Teaching in Higher Education, 9, (3), 363-375.

Hake, R. R., (1998). Interactive-engagement vs. traditional methods: a six-thousand-student survey of mechanics test data for introductory physics courses. American Journal of Physics, 66(1), 64-74.

Henderson, C., \& Dancy, M. H (2008) Physics faculty and educational researchers: Divergent expectations as barriers to the diffusion of innovations. American Journal of Physics, 76(1), 79-91.

Harmin, M. (2006). Inspiring active learning: A complete handbook for today's teachers. Alexandria, VA, USA: Association for Supervision \& Curriculum Development.

Huberman, M. (1993). Steps toward a developmental model of the teaching career. In L. Kremer-Hayon, H. C. Vonk, \& R. Fessler (Eds.), Teacher professional development: A multiple perspective approach. Amsterdam: Swets \& Zeitlinger B.V.

Johnson, D. W., Johnson, R. \& Smith, K. A. (1998). Active learning: Cooperation in the college classroom (2nd ed.). Edina, MN: Interaction Book Company.

Jose, J. C., \& Pedrosa, H. (2005). Teaching for quality learning in chemistry. International Journal of Science Education. 27(9), 1123-1137.

Kember, D. (1997). A reconceptualisation of the research into university academics' conceptions of teaching. Learning and Instruction, 7, 255-275.

Kramer, L., Brewe, E., \& O'Brien, G. (2008). Improving physics education through a diverse research and learning community at Florida. ASP Forum of Education. Retrieved from http://www.aps.org/units/fed/newsletters/summer2008/kramer.cfm

Mazur, E. (1997). Peer instruction - A user's manual. New York: Prentice-Hall.

Niemi, H. (2002). Active Learning - A cultural change in teacher education and schools. Teaching and Teacher Education, 18, 763-780.

Pundak, D., Maharshak, A., \& Rozner, S. (2004). Successful pedagogy with web assignments checker. Journal of Educational Technology Systems, 33(1), 67-80.

Pundak, D., \& Rozner, S. (2006). Dealing with the resistance of faculty to innovative teaching methods: A case study. Al Hagova - Journal on Teaching in Higher Education, 5, 4-7. (In Hebrew). 
Pundak, D., \& Rozner, S. (2007). Empowering engineering college staff to adopt active learning methods. Journal of Science Education and Technology, 17(2)152-163. Retrieved $9^{\text {th }}$ May, 2009 from http://www.springerlink.com/content/h46m45057240r016/

Pundak, D., Rozner, S., Yacobson, F., \& Toledano-Kitay, D. (2008). How to adopt active learning? Al Hagova - Journal on Teaching in Higher Education, 7, 18-21.

Redish, E. F. (2003).Teaching physics with the Physics Suite. Hoboken, NJ: Wiley.

Resnick, L.B. (1987). Education and learning to think. Washington, D.C.: National Academy Press.

Rogers, E. M. (1995). Diffusion of innovations. New York: Simon \& Schuster.

Samuelowicz, K., \& Bain, J. D. (2001). Revisiting academics' beliefs about teaching and learning. Higher Education, 41, 299-325

Scheyvens, A., Amy, L., \& Griffin, B. (2008). Experimenting with active learning in geography: Dispelling the myths that perpetuate resistance. Journal Geography in Higher Education, 32(1), 51-69

Slater, T. F., (2003). When is a good day teaching a bad thing? The Physics Teacher, 41(7), 437-438.

Snellman, E., Krueger, J., \& Unangst, E. (2006, Mar-Apr). Moving research into the classroom: Successful adaptations at a service academy. Journal of College Science Teaching, 35(5), 32-36,

Vygotsky, L. (1978). Mind in society. Chapter 6: Interaction between learning and development (M. Cole, Trans.). Cambridge, MA: Harvard University Press.

Zohar, A., \& Dori, Y. J. (2003). Higher order thinking skills and low achieving students - Are they mutually exclusive? The Journal of the Learning Sciences, 12(2), 145-182.

Zoller, U. (1987). Problem solving and decision-making in Science-Technology-Environment-Society (STES) Education. In K. Riquarts (Ed.), Science Technology Education and the Quality of Life, 2, 526569.

Zweck, J. (2006).Strategies to promote active learning in math/stat discussion sessions. Retrieved 7 July 2008 from http://www.math.umbc.edu/ zweck/TATrain/ActiveLearningStrategies.pdf

\section{Appendix: The Study Questionnaire}

This questionnaire consists of 35 statements relating to how you understand teaching. It is possible that you agree or disagree with some of them. Please rank each of statements by circling one of the numbers (from 1 to 5). The meaning of the numbers is shown in the table below.

\begin{tabular}{|l|l|l|l|l|}
\hline $\begin{array}{l}\text { 1Definitely } \\
\text { disagree }\end{array}$ & 2 Disagree & 3 Neutral & 4 Agree & 5 Definitely agree \\
\hline
\end{tabular}

Please relate to each of the statements by circling the number that best reflects your attitude. Please work quickly. There is no need to too delve deeply into each of the statements. The statements were designed to be simple and easy to understand. If you don't understand one of the statements, leave it unmarked. If you do understand the statement but don't have a clear attitude you are welcome to choose \#3.

Thank you - the research team 


\begin{tabular}{|c|c|c|}
\hline No & Item & Attitude \\
\hline 1. & $\begin{array}{l}\text { The main result of noise in a large class (more the } 40 \text { students) is that it } \\
\text { disturbs the process of learning. }\end{array}$ & $\begin{array}{lllll}1 & 2 & 3 & 4 & 5\end{array}$ \\
\hline 2. & $\begin{array}{l}\text { The instructor, besides his/her role as knowledge provider, is to guide } \\
\text { students in the process of learning. }\end{array}$ & $\begin{array}{lllll}1 & 2 & 3 & 4 & 5\end{array}$ \\
\hline 3. & $\begin{array}{l}\text { The students can, during peer discussions, discover new scientific } \\
\text { knowledge. }\end{array}$ & $\begin{array}{lllll}1 & 2 & 3 & 4 & 5\end{array}$ \\
\hline 4. & $\begin{array}{l}\text { The instructor, in addition to his/her duty as a teacher, should become } \\
\text { familiar with students' learning difficulties. }\end{array}$ & $\begin{array}{lllll}1 & 2 & 3 & 4 & 5\end{array}$ \\
\hline 5. & $\begin{array}{l}\text { Students can present in the class new ideas and arguments through their } \\
\text { own efforts. }\end{array}$ & $\begin{array}{lllll}1 & 2 & 3 & 4 & 5\end{array}$ \\
\hline 6. & Learning in large classes reduces learning efficiency. & $\begin{array}{lllll}1 & 2 & 3 & 4 & 5\end{array}$ \\
\hline 7. & $\begin{array}{l}\text { It is legitimate to test students on subjects they learned on their own and } \\
\text { that were not studied in class. }\end{array}$ & $\begin{array}{lllll}1 & 2 & 3 & 4 & 5\end{array}$ \\
\hline 8. & Students don't do weekly assignments which were not studied in class. & $\begin{array}{lllll}1 & 2 & 3 & 4 & 5\end{array}$ \\
\hline 9. & $\begin{array}{l}\text { The students' limited scientific knowledge does not allow them to build } \\
\text { new knowledge. }\end{array}$ & $\begin{array}{lllll}1 & 2 & 3 & 4 & 5\end{array}$ \\
\hline 10. & $\begin{array}{l}\text { It is important to define in the syllabus components which are very } \\
\text { important and will not be waived, and components which can be waived. }\end{array}$ & $\begin{array}{lllll}1 & 2 & 3 & 4 & 5\end{array}$ \\
\hline 11. & $\begin{array}{l}\text { Collaborative work in groups allows efficient learning in a large class } \\
\text { (more than } 40 \text { students). }\end{array}$ & $\begin{array}{lllll}1 & 2 & 3 & 4 & 5\end{array}$ \\
\hline 12. & $\begin{array}{l}\text { There is no chance to generate discussion in a large class that includes most } \\
\text { of course students (more than } 40 \text { students). }\end{array}$ & $\begin{array}{lllll}1 & 2 & 3 & 4 & 5\end{array}$ \\
\hline 13. & $\begin{array}{l}\text { It is important to require that students should submit all of their } \\
\text { assignments in basic courses. }\end{array}$ & $\begin{array}{lllll}1 & 2 & 3 & 4 & 5\end{array}$ \\
\hline 14. & The instructor should focus on his/her role as knowledge transmitter. & $\begin{array}{lllll}1 & 2 & 3 & 4 & 5\end{array}$ \\
\hline 15. & $\begin{array}{l}\text { Background noise in a large class (more than } 40 \text { students) may be an } \\
\text { indication of groups of students learning efficiently. }\end{array}$ & $\begin{array}{lllll}1 & 2 & 3 & 4 & 5\end{array}$ \\
\hline 16. & Students aren't ready to present knowledge they have learned in the course. & $\begin{array}{lllll}1 & 2 & 3 & 4 & 5\end{array}$ \\
\hline 17. & $\begin{array}{l}\text { Instructors' feedback related to preparation of assignments or summaries } \\
\text { encourage students to learn. }\end{array}$ & $\begin{array}{lllll}1 & 2 & 3 & 4 & 5\end{array}$ \\
\hline 18. & $\begin{array}{l}\text { The instructor should present to the students all of the course materials } \\
\text { during the lesson and not rely on students learning on their own. }\end{array}$ & $\begin{array}{lllll}1 & 2 & 3 & 4 & 5\end{array}$ \\
\hline 19. & $\begin{array}{l}\text { It is preferable to focus mainly on problem solving and less on formal } \\
\text { understanding of basic concepts. }\end{array}$ & $\begin{array}{lllll}1 & 2 & 3 & 4 & 5\end{array}$ \\
\hline 20. & $\begin{array}{l}\text { Discussions between students related to course materials are vital for a } \\
\text { deeper understanding of the course material. }\end{array}$ & $\begin{array}{lllll}1 & 2 & 3 & 4 & 5\end{array}$ \\
\hline 21. & $\begin{array}{l}\text { The instructor should make every effort to identify and address students' } \\
\text { learning difficulties. }\end{array}$ & $\begin{array}{lllll}1 & 2 & 3 & 4 & 5\end{array}$ \\
\hline 22. & $\begin{array}{l}\text { In large classes, during work group, the instructor has the opportunity to } \\
\text { provide personal guidance. }\end{array}$ & $\begin{array}{lllll}1 & 2 & 3 & 4 & 5\end{array}$ \\
\hline
\end{tabular}




\begin{tabular}{|c|c|c|}
\hline No & Item & Attitude \\
\hline 23. & $\begin{array}{l}\text { The final exam is not a good enough tool for providing a student feedback } \\
\text { about his knowledge and skills in the course. }\end{array}$ & $\begin{array}{lllll}1 & 2 & 3 & 4 & 5\end{array}$ \\
\hline 24. & $\begin{array}{l}\text { Students will not learn beyond what they must even in a course that } \\
\text { generates interest and curiosity. }\end{array}$ & $\begin{array}{lllll}1 & 2 & 3 & 4 & 5\end{array}$ \\
\hline 25. & $\begin{array}{l}\text { During the examination, don't ask students questions on subjects that were } \\
\text { not studied in class. }\end{array}$ & $\begin{array}{lllll}1 & 2 & 3 & 4 & 5\end{array}$ \\
\hline 26. & $\begin{array}{l}\text { The instructor may present part of the study program in class and another } \\
\text { part leave for guided learning. }\end{array}$ & $\begin{array}{lllll}1 & 2 & 3 & 4 & 5\end{array}$ \\
\hline 27. & $\begin{array}{l}\text { It is possible to teach in a meaningful way only when a student understands } \\
\text { the basic concepts. }\end{array}$ & $\begin{array}{lllll}1 & 2 & 3 & 4 & 5\end{array}$ \\
\hline 28. & $\begin{array}{l}\text { The instructor doesn't need to know the students' difficulties in his/her } \\
\text { course. }\end{array}$ & $\begin{array}{lllll}1 & 2 & 3 & 4 & 5\end{array}$ \\
\hline 29. & $\begin{array}{l}\text { There is now way for personal guidance in a large class (more than } 40 \\
\text { students). }\end{array}$ & $\begin{array}{lllll}1 & 2 & 3 & 4 & 5\end{array}$ \\
\hline 30. & $\begin{array}{l}\text { Students may be happy to have the opportunity to appear before the class } \\
\text { and present their ideas and solutions. }\end{array}$ & $\begin{array}{lllll}1 & 2 & 3 & 4 & 5\end{array}$ \\
\hline 31. & Students can be evaluated in basic courses only by means of a final exam. & $\begin{array}{lllll}1 & 2 & 3 & 4 & 5\end{array}$ \\
\hline 32. & $\begin{array}{l}\text { It is possible to create a course atmosphere where students read their task } \\
\text { assignments before the lesson. }\end{array}$ & $\begin{array}{lllll}1 & 2 & 3 & 4 & 5\end{array}$ \\
\hline 33. & $\begin{array}{l}\text { Students learn each time a limited part of course syllabus, therefore it } \\
\text { cannot be expected from them to generalize and create new scientific } \\
\text { knowledge. }\end{array}$ & $\begin{array}{lllll}1 & 2 & 3 & 4 & 5\end{array}$ \\
\hline 34. & It is important to cover the entire syllabus during the course. & $\begin{array}{lllll}1 & 2 & 3 & 4 & 5\end{array}$ \\
\hline 35. & $\begin{array}{l}\text { It is preferable to emphasize the technical aspects in problem solving over } \\
\text { the theoretical aspects. }\end{array}$ & $\begin{array}{lllll}1 & 2 & 3 & 4 & 5\end{array}$ \\
\hline
\end{tabular}

\section{Biographies}

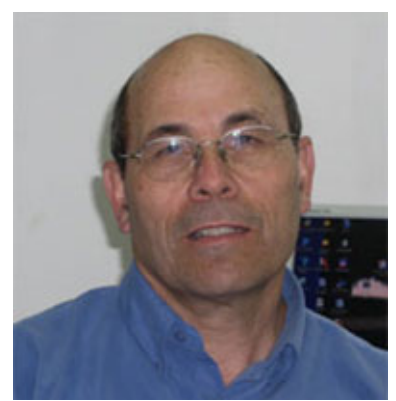

Dr. David Pundak - Senior Lecturer in Physics and faculty in Kinneret College and Head of E-Learning Unit in ORT Braude College $(\mathrm{OBC})$. For the past twenty years he has been involved in research and development in science and physics education. Having set the goal to advance science education, Dr. Pundak founded the center for science education - "Blossoms of Science" at the Kinneret College. The center integrated research done by scientists with enquiry projects conducted by junior-high and high schools students. At OBC Dr. Pundak founded and heads the E-Learning Unit which focuses on the development of courses learned through the Internet. The developed web sites enable students and instructors to take advantage of web technology and to enrich the social activities and the knowledge resources of the courses. At the same time, he studies the influence of Web technology on instruction and learning. 


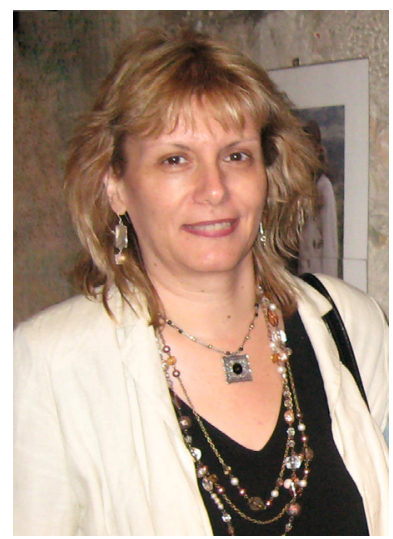

Dr. Orit Herscovitz is a Senior Adjunct Lecturer and Researcher in the Department of Education in Technology and Science, at the Technion, Israel Institute of Technology. She is also a lecturer and head of research committee in the center for Teaching and Learning at ORT Braude College. Dr. Orit Herscovitz's activities during the last 15 years at the Technion include developing and assessing case-based science curricula and promoting professional development of pre- and inservice science and technology teachers. In these two research fields she has been promoting the enhancement of constructivist learning environments via advanced educational technologies. Dr. Herscovitz has published with colleagues over 15 articles in peer-reviewed international and national journals, co-authored two book chapters. She has also written four learning units for high school students and presented papers in 20 international and over 40 national conferences.

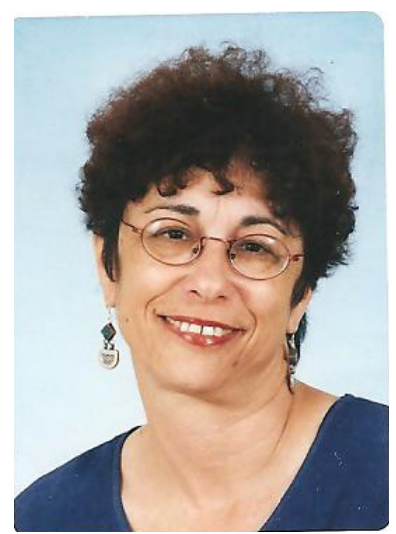

Dr. Miri Shacham works as a lecturer and researcher in the Education Department and in the Centre for Teaching and Learning of Ort Braude Academic College in Israel. She also works as a researcher in the field of Stress and Trauma in the Community Stress Prevention Centre of Tel Hai College in Israel. She is a member of an English-Israeli Team that is developing and researching a special international PhD Programme in Anglia Ruskin University in the UK. She is working also in The Israeli Ministry of Education as an Organisational Counsellor for school principals. Her major researches and publications are in these areas: Innovation in Science and Technology Education, Active Learning in Higher Education, the influence of Web technology on instruction and learning, Doctoral Education, Doctoral Learning Communities and Cross Cultural Supervision, Intercultural Learning, Stress Reactions and PTSD, Coping Resources and Community Resilience in War Times.

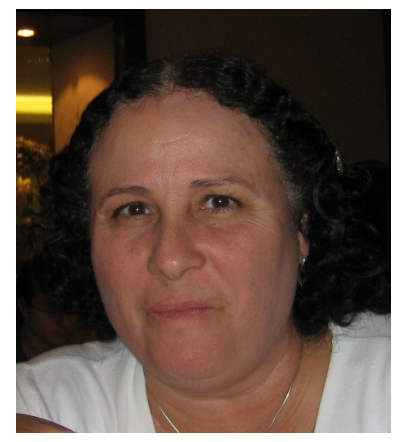

Dr. Rivka Weiser-Biton, D.Sc in Chemistry, Lecturer - Prof Ephraim Katzir Department of Biotechnology, ORT Braude College (OBC). National Collegiate Supervisor: Chemistry, Biotechnology, Food, Environment and Plastic. Dr. Weiser-Biton is the national professional supervisor of chemistry curriculum, development design, and implementation. Dr. Weiser-Biton is in-charge of national examinations and student projects in chemistry. She researched in science education in the department of science and technology education in Technion- I.I.T, Haifa, Israel. Since 1996 she has been developing courses learned through the Internet and developed web sites for the courses in ORT Braude College. She is studying the enhancement of learning in advanced technologies environments. Dr. Weiser-Biton is developing the methodology of E-Learning in the MEDA-ETE project, and since 2007 she also researching wastewater treatment. 